\title{
Guided Discovery Problem-Posing: An Attempt to Improve Science Process Skills in Elementary School
}

\section{Suryanti}

Dr., M.Pd., Primary Education Department, Universitas Negeri Surabaya, Surabaya, Indonesia, suryanti@unesa.ac.id

\section{Wahono Widodo}

Dr., M.Si., Science Education Department, Universitas Negeri Surabaya, Surabaya, Indonesia,wahonowidodo@unesa.ac.id

\section{Widowati Budijastuti}

Dr., M.Si., Biology department, Universitas Negeri Surabaya, Surabaya, Indonesia, widowatibudijastuti@unesa.ac.id

Developing science process skills in novice learners is not an easy task for teachers although these skills are essentially needed to solve problems and make decisions in real-life situasion. This research is pre-test post-test control group design. Pre-test and post-test were administered to the students in the beginning and the end of the approach to measure n-gain of students' science process skills. Students' activities in the classroom were also recorded and analysed descriptively and students' responses concerning the approach were recorded by a questionnaire given at the end of the session. Guided discovery problem-posing appeared helpful to most students for improving both basic and integrated science process skills, specifically higher order thinking skills. Students further recognized that using guided discovery problem-posing made the topics learned become easier and more entertaining.

Keywords: guided discovery, problem-posing, science process skills, higher order thinking skills, elementary school

\section{INTRODUCTION}

Science as human knowledge about nature which is obtained in a controlled manner, besides being a product that is human knowledge of science (Asy'ari, 2006). There are three dimensions in science: scientific knowledge, science process, and science focuses on the characteristics of attitude and dispositions of science (Gagne, Yekovich, \& Yekovich, 1993). Science process skills are seen as a problem-solving skill in which a problem is represented, a systematic process is carried out in order to arrive to solve the 
problem (Gagne, Yekovich, \& Yekovich, 1993). The students need the process skills both when doing scientific investigations and during their learning process (Harlen, 2000; Taconis at al., 2000). Science process skills are also believed to be able to ensure that students have meaningful learning experience because they help students develop higher order thinking (Germann \& Aram, 1996; Lee, Hairston, Thames, Lawrence, \& Herron, 2002).

Science process skills are divided into two categories, basic and integrated process skills (Martin, Sexton, \& Franklin, 2001). Basic science process skills help children to expand their learning through experience. Children begin with simple ideas and expand to form new and complex ideas. Emphasis on science process skills is expected to help children discover meaningful information and accumulate knowledge by constructing their understanding within and beyond the science classroom (Martin, Sexton, \& Franklin, 2001). According to Germann \& Aram (1996) the basic science process skills provide the intellectual groundwork in scientific enquiry. The basic process skills are the prerequisites to the integrated process skills. The integrated process skills are the terminal skills for solving problems or doing science experiments.

Science process skills should be utilized by teachers to teach the facts of science effectively. This is because science is not just of knowledge but it is a way to systematically understand the environment. Science process skills are required by students to learn about the world of science and technology in more detail. Students are able to learn science in a meaningful way through an exploration of science process skills based on the constructivist approach. The implications of constructivism for teachers of science are that the teacher has to provide the learning environment with hands-on activities that enables students to develop and master the science process skills (Yeam, 2007).

Developing science process skills via science education in elementary school has been emphasized by the Ministry of Education and Culture in Indonesia (MOEC, 2016). Yet in reality, teachers tend to focus on teaching theoretical concept rather than the science process itself (Mariana, 2017). This situation has led to low percentage of science process skills in elementary school, which is only 4.08\% (Haryono, 2006), and ironically this condition is still present in high school (Sahhyar, 2017).

Science process skills have many aspects but have something in common that is the ability to identify and solve a problem logically. Since the construction of science, science process skills depend on the process of inquiry (Ongowo \& Indoshi, 2013). Appreciation of and support for scientific enquiry imply that students can identify scientific ways of gathering evidence, thinking creatively, reasoning rationally, responding critically, and communicating conclusions, as they confront life situations related to science and technology (OECD, 2013). Problem-posing approach should be able to effectively enhance the science process skills. Problem-posing refers to the generation of new problems and to the reformulation of given problems (Silver, 1994). Problem-posing requires the student to formulate a challenging problem from presented situation or case based on the assumption that having learners construct their own solutions unguided, or with minimal guidance, leads to the most effective learning experience (Kirschner, Sweller, \& Clark, 2006). 
In order to apply problem-posing in the classroom, teachers are required to guide students to develop knowledge as a solution to a certain problem, underscoring that the students should also be able to see the problem as their own and decide how one solution is better than other alternatives (Janssen, Westbroek, \& Driel, 2009). As students see the problem as their own problem through problem-posing, it eventually builds the bridge between knowledge and real-world-contexts; thus, challenging the students to sharpen the involved science process skills through scientific investigation. In some local cases in Indonesia, problem-posing approach has been applied to improve character education, communication skills, and creative thinking (Darysyani, 2017; Sugito, Mulyani, Hartono, \& Supartono 2017; Amalina, Amirudin, \& Budiarto, 2018), but none of these have attempted to specifically see its potential to improve science process skills in novice learners.

Intriguingly, minimal guidance offered by problem-posing approach may not really help beginning learners to learn at their best. Novice learners, such as students in elementary school, use limited working memory on very heavy demands to search for problem solutions, thus the working memory cannot be used to learn and store new information (Sweller, 2004). Mayer (2004) also argued that constructing knowledge with minimal guidance can be ineffective when students do not come into contact with the new information and therefore have nothing to integrate with their knowledge base. Under this circumstance, it is important for teachers to give students specific guidance about how to cognitively manipulate information to be fit with learning goals and to store the result in long-term memory (Kirschner, Sweller, \& Clark, 2006); which can actually be achieved with instructional approach called guided discovery.

Guided discovery refers to a learning environment in which the teacher provides systematic guidance focused on the learning goals. When guided discovery is used to align with problem-posing, teacher can assist students in posing a new problem from designated subject before the lecture or after given an example of science process (Hiebert \& Wearne, 2003). This also means that teacher may provide hints, directions, coaching, feedback, and/or modelling to keep the student on track; and expository methods, in which the student is given the problem along with the correct answer (Mayer, 2004). As the students receive sufficient support in building the knowledge, guided discovery learning potentially makes the students become more engaged in the classroom and understand how knowledge is specifically constructed (Reiser, 2004).

Reiser (2004) further argued that guided discovery learning becomes an effective framework in science education as long as the teacher adequately provides support in two ways: (1) sequencing the problems into stepwise sub problems, and (2) evaluating students' solutions in such a way that the developed solutions can be improved. This gives us the rationale that problem-posing approach would be more promising to be applied in science education using the platform of guided discovery learning. If the problem posed by the students is divided into sub problems, students are motivated to solve the next problems, and ultimately experience the problems as their own. The experience of possessing their own problem is also strengthened when the students are facilitated to problematize their own created solutions, leading them to evaluate each decision and improve their own solutions. 


\section{Research Problem}

The purpose of the present research was to investigate the development of science process skills in classrooms where the students were introduced to learn science using problem-posing approach incorporated with guided discovery learning. The research questions:

1. Does guided discovery problem-posing facilitate the improvement of students' science process skills?

2. What are the student responses after learning with guided discovery problem-posing?

\section{LITERATURE REVIEW}

Science process skills is the skills required in the processes of designing and conducting scientific experiments or investigations to solve problems, comprises of two different parts: basic and integrated (Turiman, Omar, Daud, \& Osman, 2012). The basic science process skills consist of observing, classifying, measuring and using numbers, generating inference, predicting, communicating, and using the relations of time and space, whereas the integrated science process includes interpreting data, controlling variables, formulating hypotheses and doing an experiment. Science process skills become essential in science education because these skills allow the students to develop their understanding or their ability to use relevant science evidence in solving problems and making decisions (Harlen \& Qualter, 2004).

Science education is constructed upon practice and interpretation. Both science and real life give problems to be solved. It is one of a reasons why problem-posing approach could be effectively implemented in science education hoping that student can put it into practice when solving problem in real life (Akınoğlu \& Tandoğan, 2007). With our knowledge and technology advancing at a fast pace, only an individual with science literate capability, who knows how to learn, how to think logically and critically, and how to solve problem creatively, will prevail (Çakir \& Sarikaya, 2010). Klaassen (1995) argued that problem-posing is an approach to bring students in position that they themselves come to pose the main problems on which they are going to work. Problemposing situations are categorized into: (1) free (pose a problem which is difficult), (2) semi-structured (pose a problem given by equation, photograph or figure), and (3) structured (pose a problem which is reconstruction from initial problem or solution of problem) (Stoyanova \& Ellerton, 1996).

Elementary school students function as beginning learners who learn particular skills in particular contexts, but they are not able to transfer skills from one subject to another (Harlen \& Qualter, 2004). This is why, especially at the primary level, students with process skills in daily life or in certain subject cannot utilize the same skills in science. It is quite difficult for them to use the appropriate process skills without a substantial amount of practice, specific instruction, or guided strategy (Roth \& Roychoudhury, 1993). The rationale behind applying guided discovery problem-posing is to provide the assistance in constructing problem within contextual science activities.

\section{METHOD}

\section{General Background of Research}

This research is pre-test post-test control group design (Fraenkel, Wallen, \& Hyun, 2012). 
$$
\mathbf{O}_{1} \mathbf{X} \quad \mathbf{O}_{2}
$$

With:

$$
\begin{array}{lll}
\mathbf{O}_{1} & \mathrm{C} & \mathbf{O}_{2}
\end{array}
$$

$\mathrm{O}_{1}$ : Pre-test score, $\mathrm{O}_{2}$ : Post-test score, X: Guided Discovery Problem-Posing Approach; C: Control Approach

During science class, student was guided discovery problem-posing approach for two consecutive topics (i.e.: ecosystem and food webs/chains) was applied to the students. Science process skills were both at the beginning and at the end of guided discovery problem-posing approach. The lesson segments generally follow five phases of guided discovery approach proposed by Janssen, Tigelaar, \& Verloop (2014): (1) identify the significance of the topics learned as a whole; (2) this significance is reformulated as a problem to be solved by the students; (3) devise one or more solutions to the problem; (4) consider possible disadvantages of the proposed solutions; (5) narrow down the solutions based on the least number of disadvantages.
\end{abstract}

\title{
Instruments
}

Student's science process skills were measured by Science Process Skills Assessment Sheet (SPSAS). SPSAS was valid and reliable. The SPSAS consist of six skills: (1) observing, (2) classifying, (3) formulating a problem, (4) creating the hypotheses, (5) conducting experiment, and (6) drawing a conclusion.

\section{Research Sample}

The calculation of the sample number was based on the Slovin formula, that was the sample $=$ [population $/\left(1+\mathrm{e}^{2} \times\right.$ population) $]$ with error tolerance e $=5 \%$ (Sevilla, Ochave, Regala, \& Uriarte, 1984; Tejada, \& Punzalan, 2012). Participants of this research were $5^{\text {th }}$ grade students $(n=50$ of experiment group and $n=69$ of control group) in Labs Elementary School of Surabaya State University, Indonesia.

\section{Classroom Procedure}

Topics chosen to apply guided discovery problem-posing approach were ecosystem and food chain. For instance, ecosystem signifies the interdependence of biotic components (living organisms) and abiotic components (e.g. water, soil, sunlight).

- This significance was formulated into a problem by the students, for example whether the number of algae affected the freshwater snails' activity.

- To guide the students to pose adequate questions, the teacher provided a worksheet containing questions with multiple blanks.

- As the students found the missing words, they practically created their own questions with key concepts of the topics learned.

- Students were subsequently guided to conduct investigation by constructing simple aquatic ecosystem in two aquariums with two different settings: one with adequate number of algae and another without algae.

- Through the questions in the aforementioned worksheet, students observed freshwater snails' activity and collected series of data.

- A week after the observation, the teacher challenged their thinking process to determine whether the freshwater snails could survive either without algae or 
without water. This phase purpose to knowing students explore available solutions and possible disadvantages, thus finally inferring that the survival of freshwater snails depends on the availability of water and algae (biotic and abiotic components). The same lesson segments were subsequently used by the teacher to deal with unbalanced food chains/webs because of a wildfire.

\section{Data Collection and Analysis}

To assess whether the guided discovery problem-posing method was effectively performed, two observers were asked to monitor how well the teacher established the lessons. Pre-test and post-test were also scored to assess the learning gain (n-gain), indicating whether the students improved their science process skills both at the beginning and at the end of guided discovery problem-posing approach. Students' activities in the classroom were also recorded and analyzed descriptively and students' responses were recorded by questionnaire given in the end of the session.

\section{FINDINGS}

\section{Student's Science Process Skills}

Student's science process skills were measured with a test given at the beginning of guided discovery problem-posing approach (i.e. topic one: ecosystem) and at the end of the approach (i.e. topic two: food chain). Difference of number of students gaining excellent score between the first and second topics was used to estimate the n-gain scores.

\footnotetext{
Introduction

\section{ECOSYSTEM}

Organisms need food supply to survive. They cannot live by themselves. For example, you often find freshwater snails live in rivers or lakes covered with algae or water plants. In this type of environment, freshwater snails are actively moving, breathing, and even, breeding!

\section{Formulating problem}

Make a group of three or four. Please discuss with your team and generate a problem that can be investigated based on the introduction above. The problem can be formulated by completing these blanks.

\section{Constructing hypothesis}

Does the number of ... affect the activity of ...?

Now, before the investigation starts, it is better if you explain what you expect to happen.

Let's design our investigation!

Number of ... affects the activity of ...

You will need:

1. Two glass jars with lids/covers

2. Pebbles or sands

3. Water from nearby ponds, or tap water

4. Algae (approx. 10 shrubs; for Jar A), and no algae (for Jar B)

5. Four freshwater snails in same size (two snails for each jar)
}

Box 1

Student's Worksheet used in the First Topic 
Result showed that there is a comparable improvement of students' science process skills from the first topic to the second topic (Table 1), indicating an increase in student's conceptual understanding when they become familiar with guided discovery problem-posing activities. This improvement also possibly resulted from the change of problem-posing situation between the first and the second topic. In the first topic, the teacher applied 'semi-structured' problem-posing in the format of "two-step problem" as the students were encouraged to investigate two or more possible variables constituting a problem or question based on the given materials (in Box 1).

In the second topic the teacher shifted into 'structured' problem-posing in the format of "one-step problem" by inviting the students to play a card game with a goal of investigating how one definite variable disrupts another variable (excerpt showed in Box 2).

\section{Introduction}

\section{FOOD CHAINS AND FOOD WEBS}

The same group of organisms, called population, interacts with other groups of organisms because some of them, such as green plants, can produce food (sugar), while some of the others, such as animals, cannot make their own food and must eat plants and/or other animals. One day, in a very hot and dry summer, a fire suddenly appears in the grassland.

\section{Formulating problem}

Make a group of three or four. Please discuss with your team and generate a problem that can be investigated based on the introduction above. The problem can be formulated by completing these blanks.

\section{Does the grass fire affect the population of...?}

\section{Constructing hypothesis}

Now, before the investigation starts, it is better if you explain what you expect to happen.

\section{The grass fire affects the population of ...}

\section{Let's design our investigation!}

You will need: cards depicting various animals and plants in grassland, sticky tape, and yarns.

Rules of the game: One food source can only be shared between two animals.

This is the time to play with your cards to see how the population changes after a wildfire! You will remove four cards of the plant after the grass fire happens. Rearrange the food chain if there are more than two animals connected to one food source.

\section{Box 2}

Student's Worksheet used in the Second Topic

Specifically, Table 1 also highlighted that the slightest improvement of science process skills comes from analyzing data $(10 \%)$, whereas the dramatic increase comes from higher order thinking $(85 \%)$. In this research, higher order thinking was measured as skills to develop sets of problem-solving strategies to tackle unfamiliar problems or questions. Moderate gain $(20 \%-40 \%)$ can be seen in skills involving formulating 
problem, constructing hypothesis and table/diagram, generating inference, and applying concepts in advanced problem. Hence, this study clearly demonstrated that guided discovery problem-posing approach has a considerable effect in improving overall student's science process skills.

Table 1

Student's Science Process Skills in Response to the Guided Discovery Problem-Posing

\begin{tabular}{|c|c|c|c|c|c|c|c|}
\hline \multirow{2}{*}{$\begin{array}{l}\text { Science } \\
\text { skills }\end{array}$} & \multicolumn{3}{|c|}{$\begin{array}{l}\text { Topic 1: Ecosystem } \\
\text { (number of students) }\end{array}$} & \multicolumn{3}{|c|}{$\begin{array}{l}\text { Topic 2: Food chain } \\
\text { (number of students) }\end{array}$} & \multirow{2}{*}{$\begin{array}{l}\text { Gain } \\
\text { (Excellent) }\end{array}$} \\
\hline & Excellent & Good & $\begin{array}{l}\text { Poo } \\
\mathrm{r}\end{array}$ & Excellent & Good & $\begin{array}{l}\text { Poo } \\
\mathrm{r}\end{array}$ & \\
\hline $\begin{array}{l}\text { Formulating } \\
\text { problem }\end{array}$ & 16 & 4 & - & 20 & - & - & $4(20 \%)$ \\
\hline $\begin{array}{l}\text { Constructing } \\
\text { hypothesis }\end{array}$ & 12 & 4 & 4 & 20 & - & - & $8(40 \%)$ \\
\hline $\begin{array}{l}\text { Constructing } \\
\text { table/interpreting } \\
\text { diagram }\end{array}$ & 10 & 7 & 3 & 15 & 4 & 1 & $5(25 \%)$ \\
\hline $\begin{array}{ll}\text { Analysing } & \text { or } \\
\text { classifying data }\end{array}$ & 15 & 2 & 2 & 17 & 2 & 1 & $2(10 \%)$ \\
\hline Inferring & 1 & 15 & 4 & 16 & 1 & 3 & $15(75 \%)$ \\
\hline $\begin{array}{l}\text { Advanced } \\
\text { application }\end{array}$ & 9 & 4 & 7 & 16 & 2 & 2 & $7(35 \%)$ \\
\hline $\begin{array}{l}\text { Higher } \\
\text { thinking }\end{array}$ & 0 & 15 & 5 & 17 & 2 & 1 & $17(85 \%)$ \\
\hline
\end{tabular}

\section{Student's Activity and Response during Guided Discovery Problem-Posing}

There are four student's activities observed in this research: formulating problem, active learning, making arguments, and asking questions. The most dominant student's activity during the lesson is formulating problem $(42 \%)$.

Table 2

Student Activity during Lesson

\begin{tabular}{lc}
\hline Student activity & $(\%)$ \\
\hline Formulating problem & 42 \\
Active learning & 24 \\
Making arguments & 23 \\
Asking question & 11 \\
\hline
\end{tabular}

Active learning and argumentation are the second activity the students most likely demonstrated. The least demonstrated activity is asking question (Table 2). There was no irrelevant behavior during the lesson.

Table 3

N-gain of Student's Science Process Skills

\begin{tabular}{lllll}
\hline N-gain of Science Process Skills & & & \\
\hline Group & $\mathrm{N}$ & Mean & Std. Deviation & Std. Error Mean \\
\hline Control & 69 & 0.29 & 0.14 & 0.01 \\
Experiment & 50 & 0.49 & 0.22 & 0.03 \\
\hline
\end{tabular}


Table 4

Result of Independent Samples Test

\begin{tabular}{lllllll}
\hline Independent Samples Test & & & & & \\
\hline N-gain of science process skills & $\begin{array}{l}\text { Mean } \\
\text { Difference }\end{array}$ & $\begin{array}{l}\text { Std. Error } \\
\text { Difference }\end{array}$ & df & t & $\begin{array}{l}\text { Sig.(2- } \\
\text { tailed) }\end{array}$ \\
\hline Group of Experiment and Control & -0.20 & 0.03 & 117 & -5.87 & 0.00 \\
\hline
\end{tabular}

$\alpha=5 \%$

Table 4 shows that the difference in mean $\mathrm{N}$-gain of science process skills for groups: experiment and control is -0.20 and successively have degrees of freedom $(\mathrm{df})=117$ giving a $t$ value of: -5.87 . The score is significant, because sig $<.05$. Because sig $<.05$, it is clear that there is a significant difference in the mean $\mathrm{N}$-gain of science process skills in the group experiment and control each at $\alpha=5 \%$. Table 4 and 5 showed the results of the above analysis shows that the average N-gain of student's science process skills is higher after learning with the guided discovery problem-posing (experiment group) when compared to the conventional approach (control group).

Table 5

Positive Response Reported by the Students after Using Guided Discovery ProblemPosing

\begin{tabular}{lc}
\hline Statements & $(\%)$ \\
\hline Science class becomes entertaining & 99.3 \\
It is easier to understand the topics learned & 95.8 \\
I can improve my science process skills & 93.0 \\
This approach helps me formulate problems & 96.2 \\
This approach helps me generate hypotheses & 86.0 \\
This approach helps me generate questions myself & 93.4 \\
This approach helps me answer questions from my friends & 96.1 \\
This approach should be applied in the next science topics & 97.2 \\
This approach should be applied in the other classes & 95.5 \\
\hline
\end{tabular}

Based on the questionnaire (Table 5), most students preferred guided discovery problem posing to be used in the science classroom. The students stated that guided discovery problem-posing was entertaining. The approach also made them understand the topics easily and helped them improve science process skills. Most of the students also agreed that guided discovery problem posing assisted them in generating problems and hypothesis, asking questions, and answering questions from their friends. Furthermore, the students reported positive expectations that guided discovery problem-posing should be used in the other topics and lessons.

\section{DISCUSSION}

Science process skills are inseparable constituents of science education's goal in order to foster scientific literacy (AAAS, 2009). These skills, however, are difficult to teach to the beginning learners, especially in elementary grades, who are new to scientific reasoning and are rarely involved in practical activities. This research generally showed that science process skills can be acquired by elementary school students through problem-posing approach that is incorporated into guided discovery learning. Susantini (2016) stated the skills proven to be nurtured include basic science process skills, such 
as observing, communicating, classifying, and integrated science process skills, such as formulating problem and hypothesis, analyzing data, experimenting, and generating conclusion. It also appears that guided discovery problem-posing drives the students to think critically and creatively, which constitutes higher order thinking.

This finding is relevant to a recent study performed by Mishra \& Iyer (2015), describing that problem-posing can actually be implemented as an instructional strategy and that it enhances conceptual understanding and creativity. This is also in line with students' responses, in which almost all of them indicated that the topics became easy to comprehend. Indeed, incorporation of problem-posing with guided discovery leads the students to a wide range of science activities which have a great value for developing science process skills.

The first key strategy of employing guided discovery problem-posing to improve science process skills in this research is performing simple classroom activity which is concurrent with content knowledge. For instance, in this research, when the teacher needed to deliver a topic about ecosystem, the initial engaging classroom activity was showing a picture of freshwater snails' aquarium and asking the students to generate questions, such as, "Why are there many algae in the surrounding of the snails?" or "Why are the snails maintained in the water?" Students were then encouraged to propose hypotheses, collect data, and explain certain analytical questions based on what they saw when they took care of the freshwater snails themselves. At the end of the observation, it was easy to start a discussion of interdependence amongst living organisms and environment. Exposing the students to the actual environment, both outside the classroom and in the science laboratory, highly promotes science process skills because students are able to relate their findings from their observation to their learning process (Osman \& Vebrianto, 2013).

In another situation involving food chains or food webs, students were invited to a play cards displaying producers (autotrophs), primary consumers (herbivores), and secondary consumers (carnivores). Asking the students to simply draw arrows depicting "who-eatwho" and planting a grass fire scene stimulated the classroom to pose questions, such as, "What are the effects of the grass fire to the population of rabbit?" The students eventually generated a conclusion on how multiple food chains are linked together and form balanced food webs. Building mental representations on the non-abstract classroom activities tied specifically to the context provide useful and essential learning cues to develop science process skills (Roth \& Roychoudhury, 1993).

The second key strategy of science process skills improvement through this approach is a step-by-step adjustment in problem-posing situation. In this research, we unintentionally employed two distinct situations of problem-posing: "semi-structured" during the first topic and "structured" situation during the second topic. A problemposing situation is referred as "structured" when problem-posing activities are based on a specific problem, whereas semi-structured refers to a situation when students are given an open situation and are invited to explore the structure of that situation and to complete it by applying knowledge, skills, concepts, and relationships from their previous knowledge (schemata) (Van Harpen \& Sriraman, 2013).

International Journal of Instruction, July $2020 \bullet$ Vol.13, No.3 
This research revealed that elementary school students improve their science process skills better as the teacher shifts the problem to a semi-structured situation by formatting the research question in an investigable form. Perhaps, starting problem-posing in a structured situation helps the students recognize problem structures, then assists them in generating problems in an unfamiliar, unstructured situation in the future context. In a practical use, when the approach is first introduced, the teacher is recommended to provide a worksheet containing relevant question or problem or sentence with omitted words that creates an opportunity for students to recognize how to perform each science process skills (i.e. posing a problem, formulating hypothesis, collecting and analyzing data, and generating conclusion).

In line with Lowrie (2002), it is also important to first introduce the problem in a onestep problem, involving only one omitted word or only one manipulation of variable, such as, "How does the grass fire affect ...?" Thus, the problem is initially shaped in a structured setting. Later, after the students become familiar with the posing problems and scientific reasoning routines, the teacher can advance the strategy by utilizing a twostep problem, a task that involves two or more manipulations, for example, "What are the effect of ... to....?" Alternatively, the teacher can also totally remove some of aforementioned sections (e.g. problems, hypothesis, methods) and ask the students to provide opinions, answers, solutions, or points of view, leading to a semi-structured or even free problem-posing. In free problem-posing situation, as problems are generated from natural situation, students may have more than one appropriate solution, finally creating opportunities to brainstorm different ideas.

It is quite surprising that guided discovery problem-posing dramatically improves elementary school students' higher order thinking skills. The development of higher order thinking skills has been an utmost importance in modern education in contrast to the traditional one. Miri, David, \& Uri (2007) contemplated an understanding that higher order thinking is positioned above comprehension, such as recalling information, whereas analysis, evaluation, and synthesis would be considered higher order thinking skills. However, it is also understandable that learning experiences during this approach, which focused on analysis, evaluation, and synthesis, directly develop skills in problem solving, inferring, and generalizing in a similar or novel context, which are all helpful for students to handle unfamiliar problems or questions. In line with the current finding, Wilke and Straits (2005) \& Alfin, Fuad, Nur, Yuanita, \& Prahani (2019) argued that learning activities during science process skills training encourage higher order thinking as the students view science as a discipline of a dynamic process, not simply a static set of facts to memorize. Thus, they accept the responsibility to learn continuously as selfregulated learners.

\section{CONCLUSION}

Collectively, this research suggests that guided discovery problem-posing can improve elementary school student's science process skills. Guided discovery problem-posing appeared helpful to most students for improving both basic and integrated science process skills, specifically higher order thinking skills. Students further recognized that using guided discovery problem-posing made the topics learned become easier and more 
entertaining. Limitation of this research is the implementation of guided discovery problem-posing still in elementary school. Further research can be done to implement guided discovery problem-posing at the middle and upper level of education.

\section{REFERENCES}

AAAS. (2009). Benchmarks for science literacy: A tool for curriculum reform. Retrieved from http://www.project2061.org/publications/bsl/online/index.php.

Akınoğlu, O., \& Tandoğan, R. O. (2007). The effects of problem-based active learning in science education on students' academic achievement, attitude and concept learning. Eurasia Journal of Mathematics, Science, \& Technology Education, 3(1), 71-81.

Alfin, J., Fuad, A. Z., Nur, M., Yuanita, L., \& Prahani, B. K. (2019). Development of group science learning (GSL) model to improve the skills of collaborative problem solving, science process, and self-confidence of primary schools teacher candidates. International Journal of Instruction, 12(1), 1-18.

Amalina, I. K., Amirudin, M., \& Budiarto, M. T. (2018). Students' creativity: problem posing in structured situation. Journal of Physics: Conf. Series, 947, 012012. doi :10.1088/1742-6596/947/1/012012.

Asy'ari, M. (2006). Penerapan pendekatan sains-teknologi-masyarakat dalam pembelajaran sains di sekolah dasar. Jakarta: Departemen Pendidikan Nasional Direktorat Jenderal Pendidikan Tinggi Direktorat Ketenagaan.

Çakir, N. K., \& Sarikaya, M. (2010). An evaluation of science process skills of the science teaching majors. Procedia Social and Behavioral Sciences, 9, 1592-1596.

Darysyani, D. (2017). Problem posing learning model for developing students' natural disaster responsiveness characters in Indonesia (A Case Study in State Senior High Schools in Kerinci). Sumatra Journal of Disaster, Geography and Geography Education, 1(2), 307-314.

Fraenkel, J., Wallen, N., \& Hyun, H. (2012). How to design and evaluate research in education. New York: McGraw-Hill.

Gagne, E. D., Yekovich, C. W., \& Yekovich, F. R. (1993). The cognitive psychology of school learning. New York: Harper Collins College Publishers.

Germann, P. J., \& Aram, R. J. (1996). Student performances on the science processes of recording data, analyzing data, drawing conclusions, and providing evidence. Journal of Research in Science Teaching, 33(7), 773-798.

Harlen, W., \& Qualter, A. (2004). The teaching of science in the primary school. London: David Fulton Publishers.

Harlen, W. (2000). Teaching, learning and assessing science process skills. Assessment in Education, 6(1),129-144. http://dx.doi.org/10.1080/09695949993044.

Haryono. (2006). Learning model with improving of process skill approach. Surabaya University Learning Jurnal Volume 7(1), 1-13. 
Hiebert, J., \& Wearne, D. (2003). Developing understanding through problem solving. In H. L. Schoen (Eds.), Teaching mathematics through problem solving: Grades $6-12$ (pp. 3-13). Reston, VA: National Council of Teachers of Mathematics.

Janssen, F. J. J. M., Tigelaar, D. E. H., \& Verloop, N. (2009). Developing biology lessons aimed at teaching for understanding: A domain-specific heuristic for student teachers. Journal of Science Teacher Education, 20, 1-20.

Janssen, F. J. J. M., Westbroek, H. B., \& van Driel, J. H. (2014). How to make guided discovery learning practical for student teachers. Instructional Science, 42(1), 67-90.

Kirschner, P. A., Sweller, J., \& Clark, R. E. (2006). Why minimal guidance during instruction does not work: An Analysis of the failure of constructivist, discovery, problem-based, experiential, and inquiry-based teaching. Edu Psyc., 41(2), 75-86.

Klaassen, C. W. J. M. (1995). A problem-posing approach to teaching the topic of radioactivity (Unpublished doctoral dissertation). Utrecht University Repository.

Lee, A. T., Hairston, R. V., Thames, R., Lawrence, T., \& Herron, D. S. (2002). Using a computer simulation to teach science process skills to college biology and elementary majors. Computer Simulations Bioscience, 28(4), 35-42. http://dx.doi.org/10.1081/SAC120002714.

Lowrie, T. (2002). Young children posing problems: The influence of teacher intervention on the type of problems children pose. Mat. Edu. Res. J, 14(2), 87-98.

Mariana, N. (2017). Transforming mathematics problems in Indonesian primary schools by embedding Islamic and Indonesian contexts. (Unpublished doctoral dissertation). Murdoch University Repository.

Martin, R. E., Sexton, C., Franklin, T., \& McElroy, D. (2001). Teaching science for all children. Massachusetts: Allyn \& Bacon.

Mayer, R. E. (2004). Should there be a three-strikes rule against pure discovery learning? The case for guided methods of instruction. American Psyc, 59(1),14-19.

Miri, M., David, B-C., \& Uri, Z. (2007). Purposely teaching for the promotion of higher-order thinking skills: A case of critical thinking. Res in Sci Edu, 37, 353-369.

Mishra, S., \& Iyer, S. An exploration of problem posing-based activities as an assessment tool and as an instructional strategy. Research and Practice in Technology Enhanced Learning, 10, ID.5.

MOEC (Ministry of Education and Culture of Indonesia). (2016). Standard of content of education in primary and secondary schools. Jakarta: MOEC

OECD. (2013). Pisa 2015: Draft of science framework. Paris: OECD.

Ongowo, R. O., \& Indoshi, F. C. (2013). Science process skills in the Kenya certificate of secondary education biology practical examinations. Creative Edu, 4(11), 713-717.

Osman, K., \& Vebrianto, R. (2013). Fostering science process skills and improving achievement through the use of multiple media. J of Baltic Sci Edu, 12(2), 191-204. 
Reiser, B. J. (2004). Scaffolding complex learning: The mechanisms of structuring and problematizing student work. The Journal of the Learning Sciences, 13(3), 273-304.

Roth, W-M., \& Roychoudhury, A. (1993). The development of science process skills in authentic contexts. Journal of Research in Science Teaching, 30(2), 127-152.

Sahhyar \& Hastini, F. (2017). The effect of scientific inquiry learning model based on conceptual change on physics cognitive competence and science process skill (SPS) of students at senior high school. Journal of Education and Practice, 8(5), 120-126.

Sevilla, C. G., Ochave, J. A., Punsalan, T. G., Regala, B. P., \& Uriarte, G. G. (1984). An introduction to research methods. Quezon City: Rex Printing Company.

Silver, E. A. (1994). On mathematical problem posing. For the Learning of Mathematics, 14, 19-28.

Stoyanova, E., \& Ellerton, N. F. (1996). A framework for research into students' problem posing. In P. Clarkson (Ed.), Technology in mathematics education (pp. 518525). Melbourne: Mathematics Education Research Group of Australasia.

Sugito, Mulyani, S., Hartono, \& Supartono. (2017). enhancing students' communication skills through problem posing and presentation. International Journal of Evaluation and Research in Education, 6(1), 17-22.

Susantini, E., Faizah, U., Prastiwi, M. J., Suryanti. (2016). Developing educational video to improve the use of scientific approach in cooperative learning. Journal of Baltic Science Education, 15 (6), 725-737.

Sweller, J. (2004). Instructional design consequences of an analogy between evolution by natural selection and human cognitive architecture. Instructional Science, 32, 9-31.

Taconis, R., Ferguson-Hessler, M. G. M., \& Broekkamp, H. (2000). Teaching science problem solving: An overview of experimental work. J of Res in Sci Teac, 38, 442-468.

Tejada, J. J. \& Punzalan, J. R. B. (2012). On the misuse of Slovin's formula. The Philippine Statistician, 61(1), 129-136.

Turiman, P., Omar, J., Daud, A. M., \& Osman, K. (2012). Fostering the 21st century skills through scientific literacy and science process skills. Procedia-Social and Behavioral Sciences, 59, 110 - 116.

Van Harpen, X. Y., \& Sriraman, B. (2013). Creativity and mathematical problem posing: an analysis of high school students' mathematical problem posing in China and the USA. Educational Studies in Mathematics, 82, 201-221.

Wilke, R. R., \& Straits, W. J. (2005). Practical advice for teaching inquiry-based science process skills in the biological sciences. The America Bio Teac, 67(9), 534-540.

Yeam Koon Peng. (2007). Tahap Pencapaian dan Pelaksanaan Kemahiran Proses Sains dalam Kalangan Guru Pelatih. Universiti Sains Malaysia. 